GEOLOGICAL SURVEY CIRCULAR 351

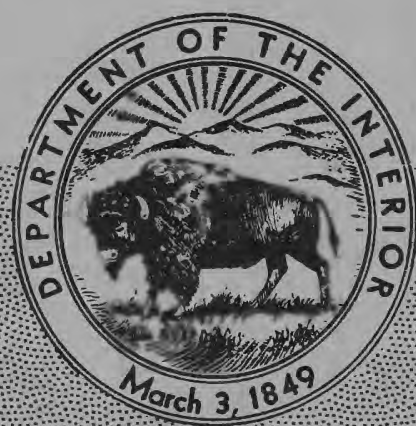

OCCURRENCES OF RADIOACTIVE

MINERALS IN THE BALD MOUNTAIN

GOLD-MINING AREA, NORTHERN

BLACK HILLS, SOUTH DAKOTA

This report concerns work done on behalf of the U. S. Atomic Energy Commission and is published with the permission of the Commission. 

UNITED STATES DEPARTMENT OF THE INTERIOR

Douglas McKay, Secretary

GEOLOGICAL SURVEY

W. E. Wrather, Director

GEOLOGICAL SURVEY CIRCULAR 351

OCCURRENCES OF RADIOACTIVE MINERALS IN THE BALD MOUNTAIN

GOLD-MINING AREA, NORTHERN BLACK HILLS, SOUTH DAKOTA

By R. C. Vickers

This report concerns work done on

behalf of the U. S. Atomic Energy

Commission and is published with

the permission of the Commission. 


\section{OCCURRENCES OF RADIOACTIVE MINERALS IN THE BALD MOUNTAIN GOLD-MINING AREA, NORTHERN BLACK HIILS, SOUTH DAKOTA}

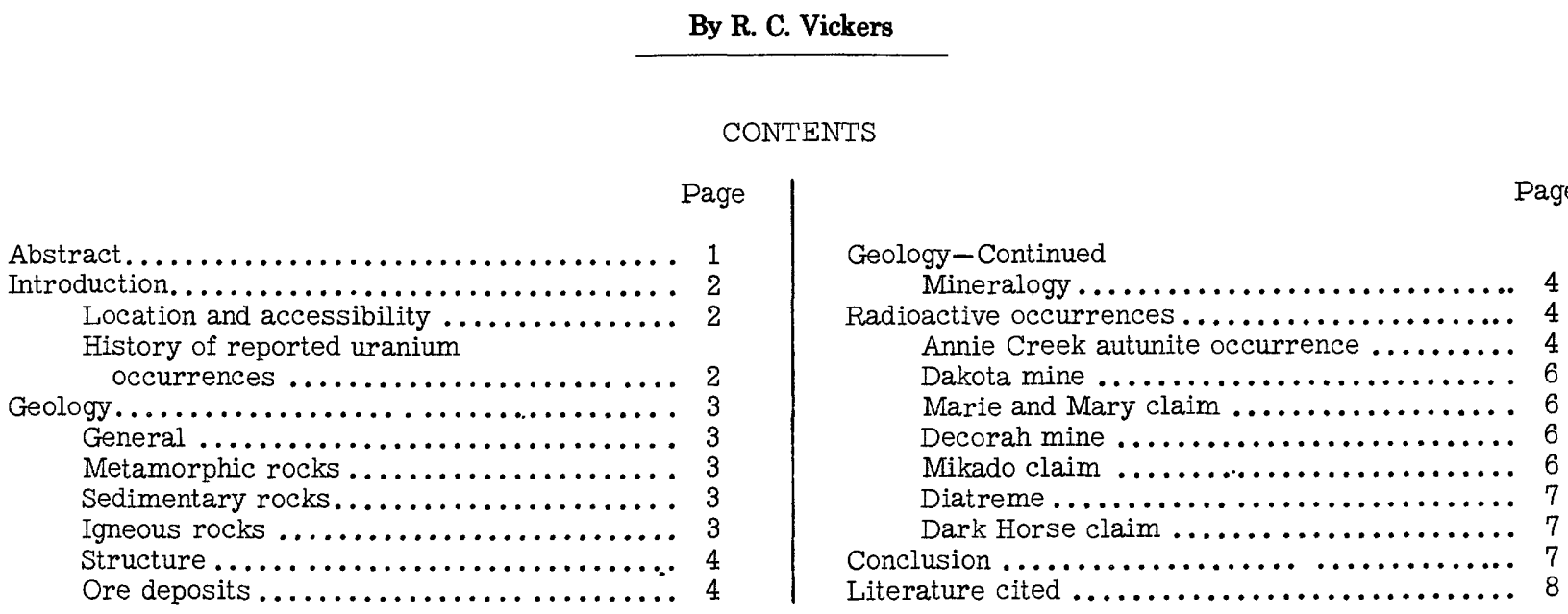

\section{ILLUSTRATIONS}

Figure 1. Index map showing location of radioactive occurrences, Bald Mountain gold-mining area,

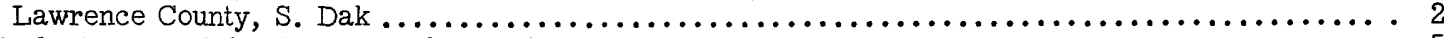

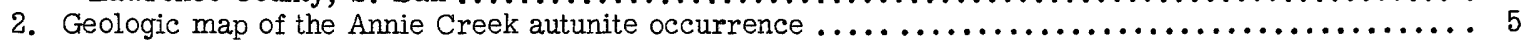

TABLES

Page

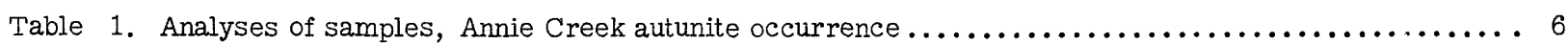

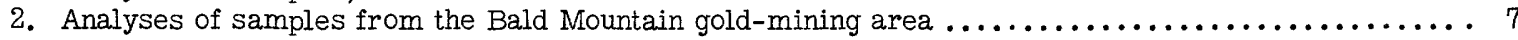

\section{ABSTRACT}

Six radioactive occurrences were found in July 1953 during a reconnaissance of the Bald Mountain gold-mining area, Lawrence County, S. Dak.

The rocks in the area consist mainly of the flatlying Deadwood formation of Cambrian age intruded by many sills, laccoliths, and dikes of Tertiary age. Associated with the intrusive rocks are gold-silver deposits which have been interpreted as being localized by solutions migrating up fractures and replacing favorable beds, mainly in the Deadwood formation. The radioactive occurrences are in fractured and altered siltstone of the Deadwood formation and the overlying Whitewood limestone and in altered intrusive rocks. Samples contain as much as 0.19 percent equivalent uranium and also contain thorium and the rare earths. All the occurrences are in the weathered zone, and differential leaching has probably disturbed the original thorium/uranium ratio. The increase in rare-earth content toward the center of the goldproducing area and the occurrence of uranium minerals (autunite and torbernite) on the fringe of the productive area are probably related to a zonal pattern.

Although none of the occurrences are large enough to constitute ore, uranium-bearing hydrothermal solutions were probably present during Tertiary mineralization in the Bald Mountain area and may have given rise to the carnotite-type deposits in the sediments surrounding the Black Hills. 


\section{INTRODUCTION}

Reconnaissance for radioactive materials in the northern Black Hills, South Dakota, was begun during the 1952 field season, at which time a deposit of autunite was found about 1.5 miles southwest of Trojan, Lawrence County, S. Dak. (Vickers, 1953). Many of the intrusive rocks of the northern Black Hills were abnormally radioactive (as much as 0.014 percent equivalent uranium). A subsequent study of these intrusive rocks indicated that most of the radioactivity was due to thorium.

Part of the 1953 field season was concerned with a detailed study and geologic mapping of the autunite deposit and detailed reconnaissance of mines and prospects in the Bald Mountain mining area. During this work, six additional radioactive occurrences were found.

\section{Location and accessibility}

The area of investigation includes parts of secs. 1, 2, and 3, T. 4 N., R. 2 E., and secs. 35 and 36, T. 5 N., R. 2 E., Black Hills meridian, Lawrence County, S. Dak. (fig. 1).

The area is accessible by many secondary roads and abandoned railroad grades, many of which can be negotiated only by vehicles equipped with four-wheel drive.

\section{History of reported uranium occurrences}

According to the available literature, uranium was first reported in the northern Black Hills by Stillwell (1885, p. 82). He mentions the occurrence of pitchblende and uranium mica (probably autunite) on Bald Mountain.

Scott (1897) mentioned the occurrence of a mineral with the composition of zeunerite occurring on Anna Creek at Carbonate and also at the Poisoned Ox mine near Pactola. Smith (1898, p. 419) reported that one sample from the Ross-Hannibal mine showed crystals of torbernite and assayed 255.08 ounces of silver and 0.44 ounce of gold per ton. This occurrencc of torbernite was again mentioned by Irving and Emmons (1904, p. 139-140) who stated that large quantities of a greenish uranium mica were reported in association with the ores of the Ross-Hannibal mine in Whitetail Gulch and that this deposit was similar to the occurrence of uranocircite in several localities in the productive mining region.

\section{O'Harra (1902, p. 78) states:}

Uranium minerals have been observed in various places, particularly in the Poisoned Ox mine near Pactola and in the Davier mine on Anna Creek near Portland. Uranium is also reported as occurring near Carbonate. At the Poisoned Ox mine the mineral occurs with copper in slates. In the Anna Creek property it is intimately associated with porphyry. At the latter place effort has been made to obtain the mineral in commercial quantities, but as yet success has not been attained.

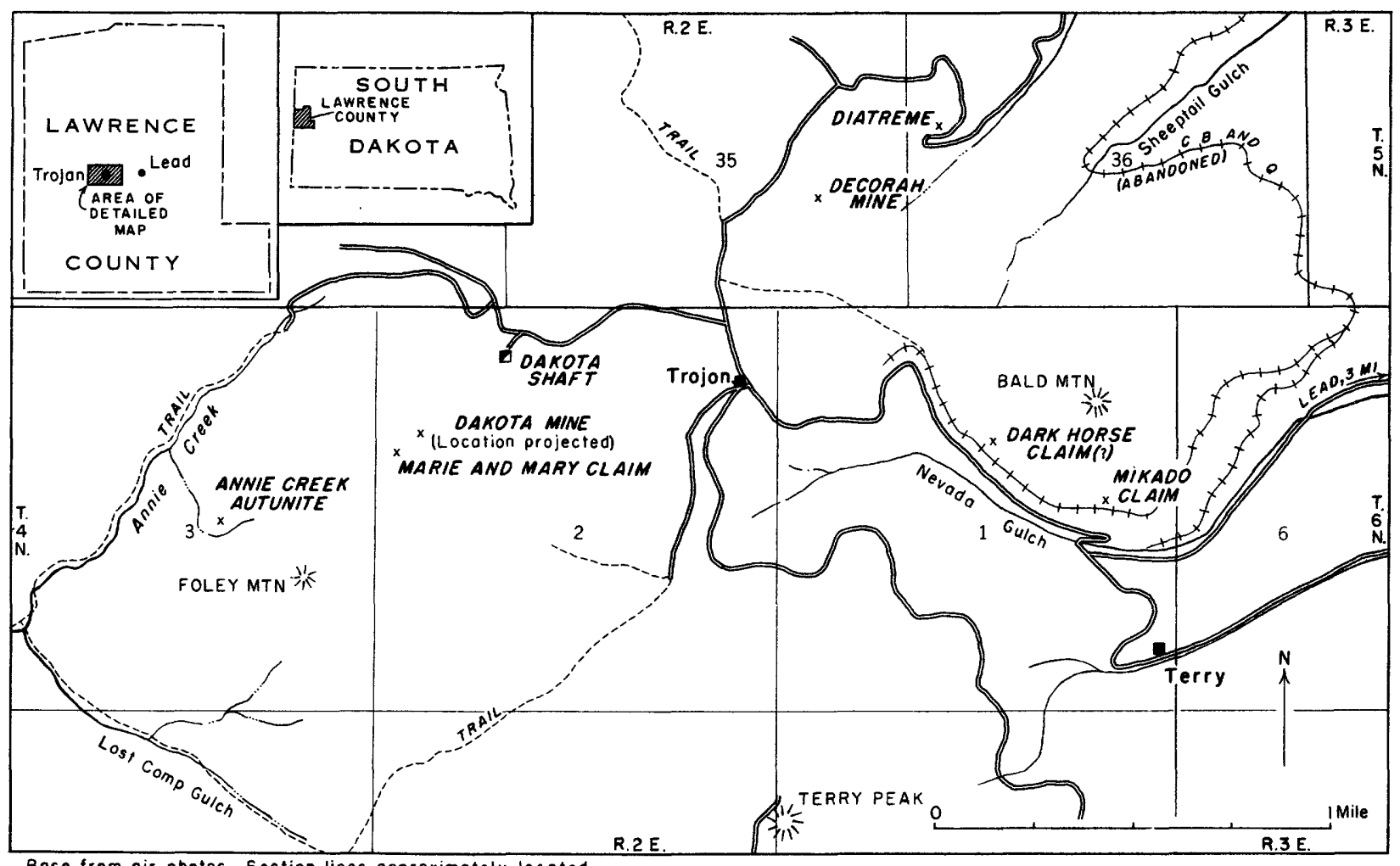

Figure 1. -Index map showing location of radioactive occurrences, Bald Mountain gold-mining area, Lawrence County, South Dakota. 
Ziegler (1914, p. 205-206) described the torbernite from the Ross-Hannibal mine as follows:

This mineral occurs in minute square tabular crystals of bright grass green color in vugs and small cavities in the blue siliceous gold ore of Lower Cambrian age, at the Ross Hannibal mine about one and one-half miles southeast of Terry.

None of the crystals attain a size larger than one-fourth of an inch square, while the majority are about one-eighth inch square. The top of these crystals has a fine pearly luster, while the sides are weakly metallic. The streak is pale green, the specific gravity about 3.5 , and the hardness 2.5-the mineral just barely ylelding a scratch by the finger nail. Torbernite possesses excellent basal cleavage, which yields an extremely thin almost micaceous, but brittle flake.

Some torbernite also occurs in very small micaceous aggregates, formed by the overlapping and intergrowth of a number of small square crystals. More commonly we find the torbernite arranged in beautiful radlating fibers pressed out flat in minute fissures in the blue siliceous ore, which yield fine almost circular rosettes up to three-fourths of an inch in diameter.

Ziegler (1914, p. 206-207) also mentions the occurrence of autunite in the porphyries (phonolite) on Annie Creek west of Portland. His description follows:

......crystals are very rare, and the autunite usually occurs as a very thin micaceous coating or a series of thin irregularly shaped flakes or as a number of small partially radiating moss-like aggregates, coating minute fissures in the porphyries. The cleavage is excellent, yielding thin brittle laminae of a lemonyellow color which are weakly transparent. The luster varles from dull silky to adamantine, while an occasional square crystal shows pearly luster. The streak is deep yellow, the hardness about equal to the finger na1l, and the specific gravity 3.07 . It is associated with limonite, and a little fluorite.

Specimens of autunite and torbernite from the northern Black Hills can be found in museums at Deadwood and Rapid City, S. Dak., at Denver, Colo., and at Chicago, $\mathrm{Il}$.

\section{GEOLOGY}

\section{General}

The general geology of the Black Hills has been summarized by Connolly (1927, p. 11), who states:

In a broad way the general structure of the Hills is simple. The Black Hills uplift is an outlier of the Rocky Mountain uplift to the west......... It has the shape of an elliptical dome whose longer axis trends northwest and southeast. The central core, consisting of metamorphic and igneous rocks, is surrounded on all sides by concentric outcrops of Paleozoic and Mesozoic sediments. The pre-Cambrian nucleus and the outwardly dipping sediments are overlapped by sediments of Oligocene age. Intruded into the pre-Cambrian metamorphic rocks and the Paleozoic and Mesozoic sediments are many dikes, sills, and laccoliths of Tertiary age,...

The most complete general geologic description of the northern Black Hills has been written by Darton and Paige (1925).

\section{Metamorphic rocks}

Pre-Cambrian rocks, which consist of amphibolite, calcareous schist, garnetiferous schist, amphibole-garnet schist, quartzite, slate, and mica schist, crop out in the central part of the northern Black Hills. These rocks are complexly folded and generally strike parallel to the main trend of the uplift and are considered to be of pre-Cambrian age.

\section{Sedimentary rocks}

Sedimentary rocks cropping out in the central part of the northern Black Hills include the Deadwood formation of Cambrian age, Whitewood limestone of Ordovician age, and the Englewood and Pahasapa limestones of Mississippian age. Ore deposits are found only in the Deadwood, Whitewood, and Pahasapa formations. Only these three formations will be further described.

Deadwood formation. - The Deadwood formation of Late Cambrian age lies unconformably on the preCambrian rocks and is divided into three parts. The basal member is a brownish-red sandstone or quartzite, usually containing lenticular beds of conglomerate at the base. The middle member is a thick series of alternating shales and dolomitic limestones, and some thin sandstone layers. The upper member is red to brown sandstone, in places quartzitic, and is commonly overlain by a few feet of shales. The Deadwood formation has a maximum thickness of about 500 feet in the northern Black Hills but thins rapidly southward. Most of the siliceous gold ore of Tertiary age in this region is in this formation.

Whitewood limestone. - Paleontologic evidence indicates that the upper 70 feet of the Deadwood formation, at the type locality, consisting of green fissile shale and gray siltstone is of Ordovician age. Furnish, Barragy, and Miller (1936, p. 1329-1341) suggest that these beds should be included with the Whitewood limestone. The green shale contains phosphatic nodules which are similar to the phosphatic nodules found in the autunite-bearing siltstone at the Annie Creek autunite occurrence. Probably some of the gold ores of Tertiary age in the northern Black Hills are in rocks classified as part of the Deadwood formation which are now believed to be of Ordovician age. No ore deposits are known to occur in the Whitewood as originally described by Darton.

Pahasapa limestone. - The Pahasapa limestone of Mississippian age is a massive-bedded gray to buff fine-grained limestone, generally dolomitic. It ranges in thickness from 300 to more than 600 feet. Only minor silver-lead-gold deposits are found in this formation.

\section{Igneous rocks}

Pre-Cambrian igneous rocks are found in the northern Black Hills but are not directly related to the mineralization in the Bald Mountain area.

Extensive igneous activity took place in this region during early Tertiary time, and many dikes, sills, laccoliths, and irregular intrusive bodies were injected into the pre-Cambrian, Paleozoic, and 
Mesozoic rocks. Paige (1924, p. 16-17) describes the following Tertiary igneous rocks from the northern Black Hills: rhyolite, rhyolite porphyry, porphyritic rhyolite, quartz monzonite porphyry, monzonite porphyry, grorudite, and phonolite.

These 7 ertiary ignecus rocks are of prime importance from the standpoint of ore deposition in the northern Black Hills because of the hydrothermal activity associated with them. The known occurrences of uranium- and thorium-bearing minerals in the region are also directly associated with the Tertiary mineralization or with the Tertiary intrusive rocks.

\section{Structure}

The principal structural features of the northern Black Hills are the dorning of the Paleozoic and Mesozoic formations, which occurred in Late Cretaceous time, and the deformation of the pre-Tertiary rocks caused by the igneous intrusions in Tertiary time.

Paleozoic and Mesozoic rocks generally dip away from the central part of the region at less than 20 degrees. This dip has been modified in places by intrusion of igneous masses into the sedimentary strata of the northern Black Hills in early Tertiary time. In the Bald Mountain mining area the sedimentary formations are nearly horizontal, and the dips are usually less than 10 degrees.

Many fractures and faults of small displacement have resulted from the intrusion of the larger igneous masses and have acted as channelways for the orebearing solutions.

\section{Ore deposits}

The gold-silver deposits of Tertiary age in the northern Black Hills have been interpreted by Connolly (1925) as hydrothermal replacement deposits that are genetically associated with extensive intrusive activity. They occur principally in the Deadwood formation. Most of the ore deposits have been formed by solutions migrating up fractures and replacing favorable beds along the upper and lower contacts of the Deadwood formation. Some of these channelways (locally termed "verticals") were sufficiently mineralized to constitute ore bodies extending for hundreds of feet vertically, but nearly all of the production has come from the replacement bodies. The ore bodies are in the form of elongate shoots, or irregular channellike bodies, roughly paralleling the strike of the major system of verticals. The largest ore bodies have been formed at the intersection of two sets of closely spaced verticals.

\section{Mineralogy}

Connolly (1927, p. 119) states that the mineralization is of a very simple type:

\footnotetext{
......The non-metallic constituents that have been introduced consist of silica, both crystalline quartz and chalcedonic silica, simple carbonates, dolomite and calcite, sulphates, barite, gypsum, and alunite, and fluorite. Silicates and heavy oxides are totally lacking. The metallic minerals are auriferous pyrite, argentiferous galena, wolframite and huebnerite, tetrahedrite, lollingite, arsenopyrite, a little chalcopyrite, stibnite, sylvanite, and calaverite.
}

Autunite, torbernite, uranocircite, zeunerite, and pitchblende have also been reported (see p. 2-3); but with the exception of autunite, none of these minerals have been mentioned in the literature on the area since 1914.

\section{RADIOACTIVE OCCURRENCES}

Abnormal radioactivity, that is, radioactivity significantly higher than that of the Tertiary igneous rocks of the area which commonly contain 0.01 percent equivalent uranium, has been found at seven localities in the Bald Mountain mining district of the northern Black Hills (fig. 1). With the exception of the autunite deposit, all the occurrences were found during the 1953 field season.

Chemical and spectrographic analyses indicate the presence of both uranium and thorium, and the occurrences range from those dominantly uranium bearing to those dominantly thorium-bearing.

Because all the deposits are in the weathered zone, differential leaching probably has disturbed the original thorium/uranium ratio.

\section{Annie Creek autunite occurrence}

Autunite, as fracture coatings and disseminations in siltstone of the Whitewood limestone of Ordovician age, was found during the 1952 field sea-

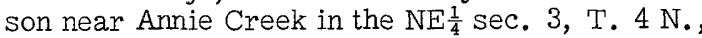
R. 2 E., Lawrence County, S. Dak. (Vickers, 1953).

The autunite-bearing siltstone is exposed in a partly caved adit that was driven just above and parallel to a nearly horizontal contact between siltstone and an underlying trachyte porphyry. A winze, now partly filled with debris, extends through the siltstone and into the porphyry (fig. 2).

During the 1953 field season the area immediately surrounding the deposit was mapped at a scale of 1 inch equals 50 feet and sampled. Further reconnaissance in the area showed abnormal radioactivity associated with an altered lamprophyre(?) dike about 200 feet west of the portal and at a small area covered with talus about 300 feet northwest of the portal. A 3-foot chip-channel sample of the dike rock contained 0.034 percent equivalent uranium and 0.013 percent uranium. The sample was extensively weathered, which probably accounts for the difference between eU and $U$ content. No appreciably radioactive rocks were found at the second anomalous area, but it is worthy of note that the anomaly lies on the projected contact between the siltstone and the underlying trachyte porphyry.

Sampling of the occurrence did not indicate material of ore grade. However, the siltstone is poorly exposed, and sample information is available only from the limited underground workings and old prospect pits. The sample data are tabulated in table 1.

Field mapping indicated a northward- and northeastward-trending system of fractures in the siltstone and to a lesser extent in the porphyry below the siltstone. The highest radioactivity was observed where 


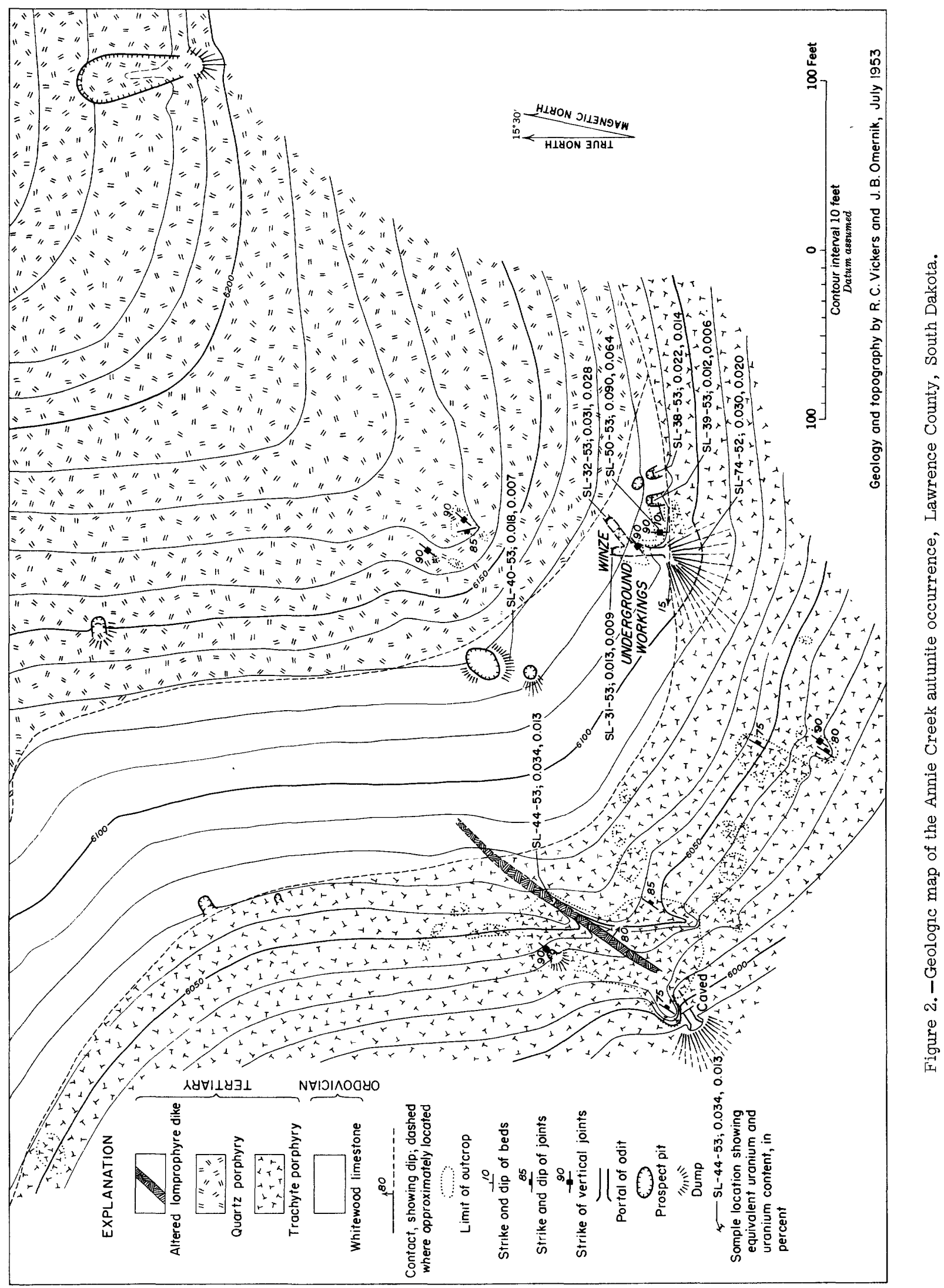


Table 1.-Analyses of samples, Annie Creek autunite occurrence, Lawrence County, S. Dak.

[Analyses by U. S. Geological Survey ]

\begin{tabular}{|c|c|c|c|}
\hline \multirow{2}{*}{ Field no. } & \multicolumn{2}{|c|}{ Percent } & \multirow{2}{*}{ Remarks } \\
\hline & $\mathrm{eU}$ & $\mathrm{U}$ & \\
\hline SL-31-53 & 0.013 & 0.009 & 4-foot chip-channel sample, across face, northward-trending adit. \\
\hline SL-32-53 & .031 & .028 & 4-foot chip-channel sample, across face, northeastward-trending adit. \\
\hline SL $-33-53$ & .043 & .029 & 16-inch channel sample, most radioactive part of face, northeastward- \\
\hline SL $-34-53$ & .060 & .057 & $\begin{array}{l}\text { trending adit. } \\
\text { l-foot channel sample, northeastward-trending adit, I foot above }\end{array}$ \\
\hline & & & $\begin{array}{l}\text { porphyry-siltstone contact. } \\
\text { polder }\end{array}$ \\
\hline SL- - & .013 & .007 & Porphyry from winze below contact. \\
\hline & .022 & .014 & 3.5-foot channel sample; pit 50 feet east of portal. \\
\hline & .012 & .006 & 3-foot chip-channel sample, pit 30 feet east of portal. \\
\hline & .018 & .007 & $\begin{array}{l}\text { Dump sample, pit northwest of adit. Also contains } 0.0 \mathrm{X} \text { percent thorium } \\
\text { as determined spectrographically. }\end{array}$ \\
\hline $\mathrm{SL}-44-53$ & .034 & .013 & 3-foot chip channel sample, dike rock. \\
\hline & .090 & .064 & Grab sample of phosphatic siltstone 10 feet east of portal. \\
\hline
\end{tabular}

the fractures were more closely spaced in the siltstone. Most of the autunite occurred as fracture-fillings in both sets of fractures. The writer believes that the uranium was introduced into the siltstone along this system of fractures and that the phosphatic and calcareous siltstone above the porphyry contact was a favorable environment for uranium deposition. The thorium content of sample SL-40-53 (0. OX percent) indicates a genetic relationship of the Annie Creek autunite occurrence to the other thorium uranium occurrences in the area.

Phosphatic nodules found about 10 feet east of the portal probably correlate stratigraphically with similar nodules which occur near the base of the Whitewood limestone at the type locality on Whitewood Creek. The age of the siltstone would then be Ordovician, instead of Cambrian as reported by Vickers.

Because of the lack of good outcrops in the area, the limits of uranium occurrence are unknown. The known extent of uranium deposition, measured across the general strike of the fracture system, is about 220 feet. If uranium-bearing solutions moved up along the altered dike as evidenced by the abnormal uranium content of the dike rock, then a favorable area of deposition might be the siltstone adjacent to or above the dike. Shallow trenching would be necessary to confirm this. Shallow trenching may also be effective in finding additional mineralized siltstone between the underground workings and the dike.

\section{Dakota mine}

During a scintillation-counter survey of the Dakota mine, NW $\frac{1}{4}$ sec. 2, T. 4 N., R. 2 E. (fig. 1), high scintillation counts were detected near the south edge of the 100-foot level. The radioactivity was associated with several narrow alteration zones in the Deadwood formation of Cambrian age. One 3 -inch wide alteration zone was sampled and contained 0.19 percent equivalent uranium, 0.10 percent uranium, $0 . \mathrm{X}$ percent thorium, and 0.23 ounce gold per ton.

The occurrence is of interest because a system of "verticals" at this locality strikes toward the Annie Creek autunite deposit, which is about 2,700 feet to the southwest.
Although economic quantities of ore-grade material were not observed, only a small part of the underground workings were examined. A detailed scintillation-counter survey of the mine and underground mapping of the occurrences are planned for the 1954 field season.

The Dakota mine is now being worked for gold by the Bald Mountain Mining Co.

\section{Marie and Mary claim}

An examination of the abandoned prospects between the Annie Creek autunite occurrence and the Dakota mine was made, and several specimens from a dump on the Marie and Mary claim were found to be abnormally radioactive (fig. 1). The workings consist of a caved adit which was probably about 60 feet long. A sample of silicified siltstone from the property contained 0.041 percent equivalent uranium, 0.007 percent uranium, and $0 . \mathrm{X}^{-}$percent thorium. This deposit is about 500 feet southwest from the surface projection of the occurrence in the Dakota mine.

\section{Decorah mine}

During a scintillation-counter survey of part of the Decorah mine, abnormal radioactivity (as much as $2.0 \mathrm{mr} / \mathrm{hr}$ ) was detected near a rhyolite porphyry dike located about 200 feet from the incline portal. A grab sample of the dike contained 0.025 percent equivalent uranium, 0.008 percent uranium, and $0.0 X$ percent thorium. The sample consisted mainly of altered rhyolite porphyry containing abundant clay minerals and limonite.

\section{Mikado claim}

Local concentrations of radioactive material were found in siltstone near a sheared contact with a porphyry dike in a railroad cut on the Mikado claim, $\mathrm{NE} \frac{1}{4} \mathrm{sec} .1$, T. 4 N., R. 2 E. A selected sample contained 0.053 percent equivalent uranium, 0.009 percent uranium, and 0.16 percent thorium. 


\section{Diatreme}

Specimens of radioactive altered diatreme material were found on an old dump about 4,000 feet northeast of Trojan, S. Dak. Analyses of three samples are listed below.

\begin{tabular}{|c|c|c|c|}
\hline \multirow{2}{*}{ Sample no. } & \multicolumn{2}{|c|}{ Percent } & \multirow{2}{*}{$\operatorname{Th}^{1}$} \\
\hline & $\mathrm{eU}$ & $\mathrm{U}$ & \\
\hline $\begin{array}{l}\text { SL-25-53-2 } \\
\text { SL-30-53- } \\
\text { SL-51-53- }\end{array}$ & $\begin{array}{r}0.045 \\
.035 \\
.032\end{array}$ & $\begin{array}{r}0.006 \\
.010 \\
.007\end{array}$ & $\begin{array}{l}\text { O. } \mathrm{x}^{-} \\
\mathrm{n} . \mathrm{d} \\
. \mathrm{O \textrm {OX } ^ { + }}\end{array}$ \\
\hline
\end{tabular}

${ }^{1}$ Determined spectrographically.

Thin sections of the diatreme material show that it is composed mainly of a breccia of pre-Cambrian rocks, such as graphitic schist and quartzite, cemented by a rhyolite porphyry. Small amounts of fluorite occur as cavity fillings in the sections.

No outcrops of the diatreme material were observed in the vicinity of the occurrence, but these outcrops about one-half mile to the north exhibited no anomalous radioactivity. The radioactive material was probably introduced after intrusion of the rock.

\section{Dark Horse claim}

At the Dark Horse claim, NE $\frac{1}{4}$ sec. 1, T. 4 N., R. $2 \mathrm{E}$., abnormal radioactivity was found associated with manganese-filled fractures in a shear zone which is partly exposed at the end of an adit 10 feet long. Selected samples of the $\frac{1}{4}$ - to $\frac{1}{2}$-inch wide manganese fracture-fillings contained 0.026 percent equivalent uranium and 0.017 percent uranium. (See table 2.)

\section{CONCLUSION}

Although minable amounts of ore-grade radioactive material have not been found in the Bald Mountain gold-mining area, the occurrences are of interest because they extend the limits of known thoriumuranium mineralization within the Black Hills area.

The results of chemical and spectrographic analyses of eight samples are shown in table 2. The analytical data indicate a progressive increase in the rare-earth content from the Annie Creek autunite deposit to the vicinity of Bald Mountain, which is near the center of the gold-producing area. Although conclusive evidence is lacking, the Annie Creek autunite deposit is believed to be on the fringe of the goldproducing area with uranium having been deposited slightly later than gold. The Ross-Hannibal mine (see p. 2-3) is also on the fringe of the productive area.

All the known radioactive occurrences are in the zone of weathering and have been found only in underground workings or on old mine dumps. Pyrite, or its weathering products, is present in all the samples, and differential leaching probably has disturbed the thorium/uranium ratios because of the greater mobility of uranium during weathering.

In the Bald Mountain gold-mining area most of the ore that has been mined and most of the mine workings have been in oxidized rock. Because the uranium is more readily transported during weathering in a pyrite gangue, minable quantities of uranium would probably occur only in relatively unoxidized ore. The torbernite at the Ross-Hannibal mine is reported to have occurred in large quantities in unoxidized ore (Irving, 1904, p. 139-140), but no mention is made of any positively identified primary uranium mine ral.

Table 2.-Analyses of samples from Bald Mountain gold-mining area, Lawrence County, S. Dak. [Analyses by U. S. Geological Survey. Spectrograppic notations, in percent: $0.0 \mathrm{X}^{-}=0.01-0.03 ; 0.0 \mathrm{X}=0.04-0.06 ; 0.0 \mathrm{X}^{+}=0.07-0.09$ ]

\begin{tabular}{|c|c|c|c|c|c|}
\hline \multirow{2}{*}{ Field no. } & \multirow{2}{*}{ Location and type of sample } & \multicolumn{2}{|c|}{ Percent } & \multirow{2}{*}{ Th. ${ }^{1}$} & \multirow{2}{*}{$\begin{array}{l}\text { Total } \\
\text { rare } \\
\text { earths }\end{array}$} \\
\hline & & $\mathrm{eU}$ & $\mathrm{U}$ & & \\
\hline SL-34-53 & $\begin{array}{l}\text { Annie Creek: } \\
\text { Autunite-bearing siltstone- }\end{array}$ & 0.060 & 0.057 & - & $0.0 \mathrm{X}$ \\
\hline $\begin{array}{l}\mathrm{SL}-40-53 \\
\mathrm{SL}-48-53\end{array}$ & Marie and Mary claim: & .018 & .007 & $0.0 \mathrm{X}$ & $.0 \mathrm{X}^{-}$ \\
\hline $\mathrm{SL}-46-53$ & $\begin{array}{l}\text { Silicified siltstone- } \\
\text { Dakota mine: }\end{array}$ & .041 & .007 & & $.0 \mathrm{X}$ \\
\hline $\mathrm{SL}-47-53$ & $\begin{array}{l}\text { Altered siltstone } \\
\text { Decorah mine: }\end{array}$ & .19 & .10 &. $\mathrm{X}$ & $\mathrm{X}^{-}$ \\
\hline$S L-51-53$ & $\begin{array}{l}\text { Altered porphyry } \\
\text { Bald Mountain: }\end{array}$ & $.0<5$ & .008 & $.0 \times$ & $\cdot X^{-}$ \\
\hline SL-25-53 & $\begin{array}{l}\text { Altered diatreme }{ }^{3} \\
3\end{array}$ & $\begin{array}{l}.032 \\
.045\end{array}$ & $\begin{array}{l}.007 \\
.006\end{array}$ & $\begin{array}{l}.0 \mathrm{X}^{+} \\
. \mathrm{X}^{-}\end{array}$ & $\begin{array}{l}. \mathrm{X}^{-} \\
. \mathrm{X}^{-}\end{array}$ \\
\hline 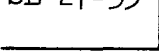 & Manganese veinlets- & .026 & .017 & & $\mathrm{X} . \mathrm{O}^{-}$ \\
\hline
\end{tabular}


The presence of uranium, thorium, and rare earths in these occurrences suggests a genetic relationship to the thorium-uranium-rare earth deposits of the Bear Lodge Mountains about $30 \mathrm{~m}$ 'les to the northwest. These deposits were described (1953) in an unpublished report by Wilmarth and Johnson.

The radioactive occurrences in the Bald Mountain mining area are of special interest because of their possible relationship to the carnotite-type deposits $n$ the sediments surrounding the Black Hills. The small scattered occurrences of hydrothermal uranium in the Bald Mountain area may reflect local conditions which precipitated uranium. Most of the uranium may not have been depos'ted but remained in solution to be mixed with and distrıbuted by ground water.

\section{LITERATURE CITED}

Connolly, J. P., 1925, Geology and mineralogy of the Keystone district [Pennington County, S. Dak.]: Black Hills Engineer, v. 13, no. 1. 1927, The Tertiary mineralization of the northern Black Hills: S. Dak. School of Mines Bull. 15.

Darton, N. H., and Paige, Sidney, 1925, Description of the central Black Hills: U. S. Geol. Survey Geol. Atlas, folio 219.
Furnish, W. M., Barragy, E. J., and Miller, A. K. 1936, Ordovician fossils from upper part of type section of Deadwood formation, South Dakota: Am. Assoc. Petrolenm Geolog sts Bull., v. 20, no. 10 , p. $1329-1341$.

Irving, J. D., 1904, Economic resources of the northern Black Hills, with contributions by S. F. Emmons, and T. A. Jaggar, Jr.: U. S. Geol. Survey Prof. Paper 26.

O'Harra, C. C., 1902, Mineral resources of South Dakota, including mineral wealth of the Black Hills: S. Dak. Geol. Survey Bull. 3.

Paige, Sidney, 1924, Geology of the region around Lead, S. Dak., and its bearing on the Homestake ore body: U. S. Geol. Survey Bull. 765.

Scott, S. E., 1897, Map of the Black Hills of South Dakota and Wyoming with full descriptions of mineral resources: Phila., E. P. Noll Co.

Smith, F. C., 1898, The Potsdam gold ores of the Black Hills: Am. Inst. Min. Met. Eng., Trans. 27.

Stillwell, L. W., 1885, Communication to the editors telling of the finding of pitchblende and uranium mica on Bald Mountain, South Dakota: Am. Jour. Sci., v. 30 , no. 175, p. 82 .

Vickers, R. C., 1953, An occurrence of autunite, Lawrence County, S. Dak.: U. S. Geol. Survey Circ. 286.

Ziegler, Victor, 1914, The minerals of the Black Hills: S. Dak. School of Mines Bull. 10. 


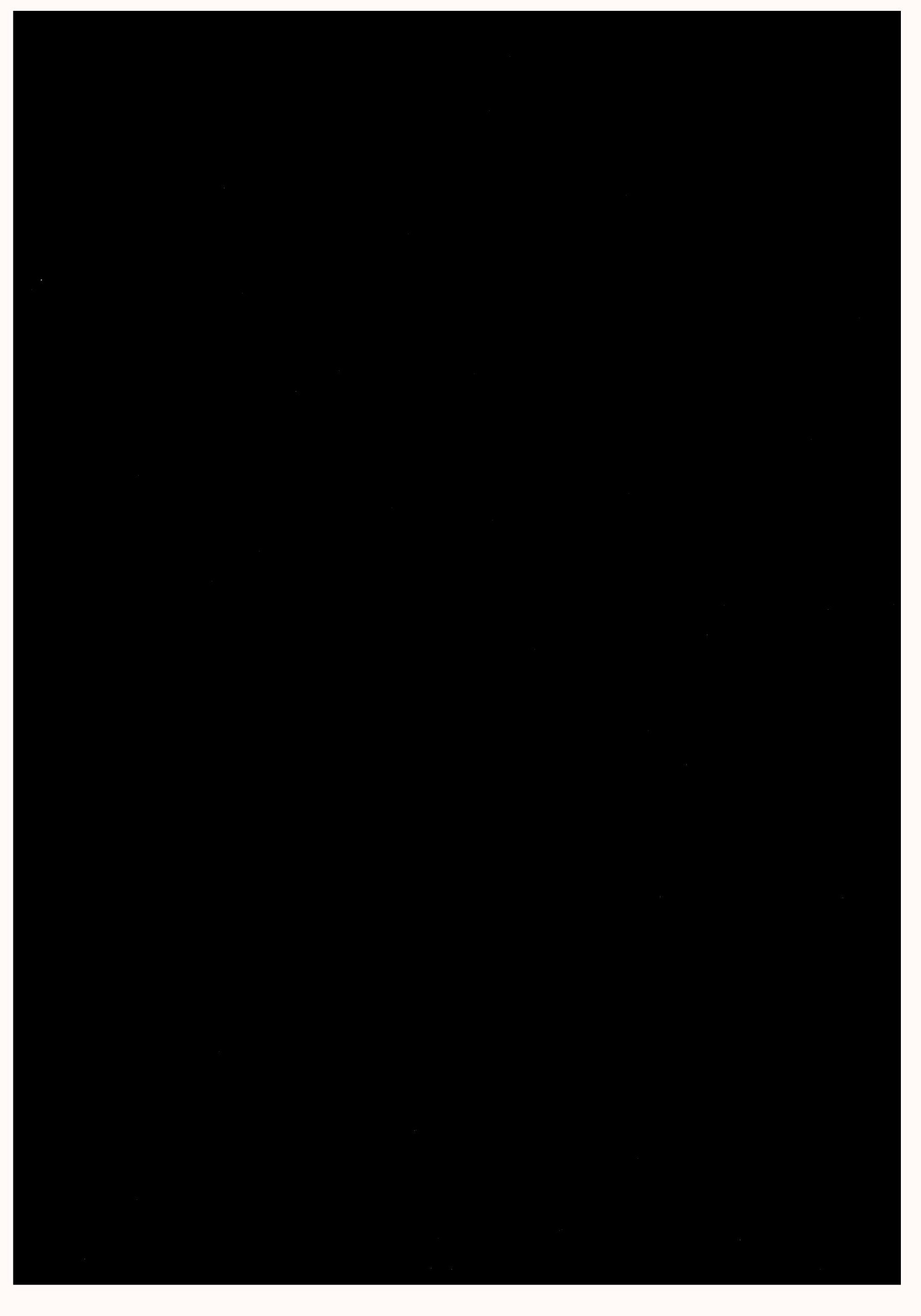




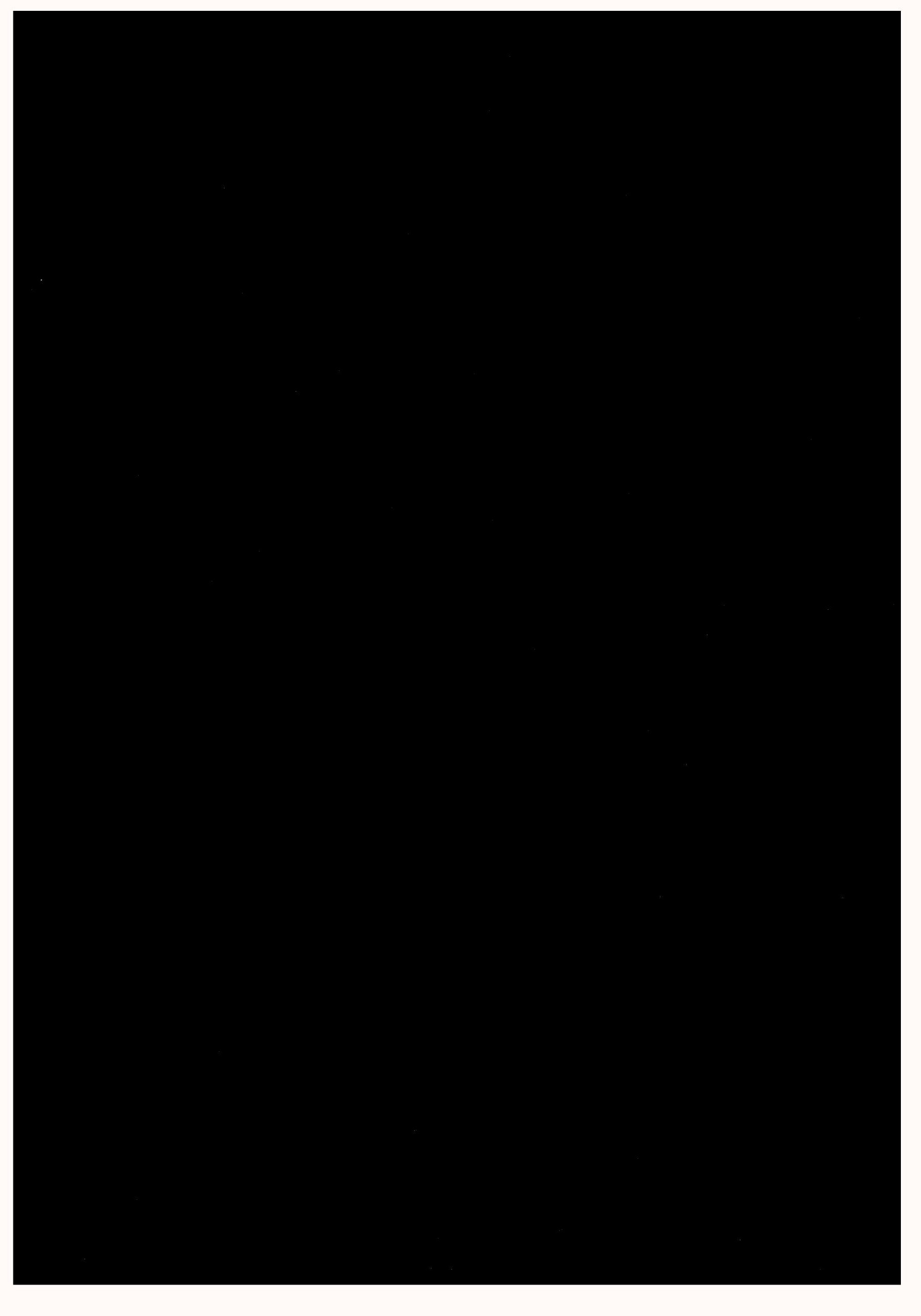

